\title{
Impact of North Korean nuclear weapons test on 3 September, 2017 on inland China
} traced by $14 \mathrm{C}$ and $129 \mathrm{I}$

\author{
Zhang, Luyuan; Hou, Xiaolin; Cheng, Peng; Chen, Ning; Fan, Yukun; Liu, Qi
}

Published in:

Journal of Radioanalytical and Nuclear Chemistry

Link to article, DOI:

10.1007/s10967-018-5747-y

Publication date:

2018

Document Version

Peer reviewed version

Link back to DTU Orbit

Citation (APA):

Zhang, L., Hou, X., Cheng, P., Chen, N., Fan, Y., \& Liu, Q.1(2818). Impact of North Korean nuclear weapons test on 3 September, 2017 on inland China traced by ${ }^{2} \mathrm{C}$ and ${ }^{2}$ I. Journal of Radioanalytical and Nuclear Chemistry, 316(1), 383-388. https://doi.org/10.1007/s10967-018-5747-y

\section{General rights}

Copyright and moral rights for the publications made accessible in the public portal are retained by the authors and/or other copyright owners and it is a condition of accessing publications that users recognise and abide by the legal requirements associated with these rights.

- Users may download and print one copy of any publication from the public portal for the purpose of private study or research.

- You may not further distribute the material or use it for any profit-making activity or commercial gain

- You may freely distribute the URL identifying the publication in the public portal 
1 Impact of the North Korean nuclear weapon test on 3rd September 2017 in inland China traced by long-lived radionuclides $\left({ }^{14} \mathrm{C}\right.$ and $\left.{ }^{129} \mathrm{I}\right)$

3

$4 \quad$ Luyuan Zhang ${ }^{1 *}$, Xiaolin Hou ${ }^{1,2 *}$, Peng Chen ${ }^{1}$, Ning Chen ${ }^{1}$, Yukun Fan ${ }^{1}$, Qi Liu ${ }^{1}$ 5

$6{ }^{1}$ State Key Laboratory of Loess and Quaternary Geology, Xi'an AMS Center, Institute of

7 Earth Environment, China Academy of Sciences, Xi'an 710075, China

$8 \quad{ }^{2}$ Center for Nuclear Technologies, Technical University of Denmark, Risø Campus,

$9 \quad$ Roskilde 4000, Denmark

10

11 Corresponding author: Hou Xiaolin, houxl@ieecas.cn;

12 Zhang Luyuan, zhangly@ieecas.cn; 


\section{Abstract}

On 3rd Sept., 2017, the sixth nuclear weapons test detonated by North Korea at the Punggye-ri nuclear test site has attracted extensive attention, of which radioactive hazard releases are the key concern, in particular in its neighboring countries including China. The released radioactive substances might be quickly dispersed to a large area through atmospheric processes. Aerosol samples were collected in Xi' an, a Chinese inland city, and analyzed for two volatile and long-lived radionuclides, ${ }^{14} \mathrm{C}$ and ${ }^{129} \mathrm{I}$, using highly sensitive accelerator mass spectrometry, to investigate possible leakage and level of radioactive substances from this nuclear weapons test. Values of $\Delta^{14} \mathrm{C}$ in the post-test samples (-485\%o to $-627 \%$ ) does not show any significant difference with those in the pre-test samples ($450 \%$ o to $-530 \%$ ), indicating no visible releases of radioactive ${ }^{14} \mathrm{C}$ from this nuclear weapons test. Compared to those observed in normal atmospheric $\mathrm{CO}_{2}$ in China (-20\% to -30\%o), the highly negative values of $\Delta^{14} \mathrm{C}$ in these aerosol samples can be attributed to the ${ }^{14} \mathrm{C}$-depleted "old carbon” from combustion of fossil fuel in urban areas in Xi'an. A fourfold increase of ${ }^{129} \mathrm{I} /{ }^{127} \mathrm{I}$ ratios of $(0.6-7.4) \times 10^{-8}$ in the post-test samples than the pre-test ones $\left((0.4-1.6) \times 10^{-8}\right)$ were observed. The possible sources of ${ }^{129} \mathrm{I}$ in these atmospheric samples and the impact of the North Korea nuclear test are discussed.

Keywords: North Korea underground nuclear weapons test, Carbon-14, Iodine-129, environmental radioactivity, aerosol 


\section{Introduction}

On 3rd Sept., 2017, at 12:00 am local time, North Korea conducted the sixth nuclear test of a hydrogen bomb. The seismic record by University of Science and Technology of China and Chinese Academy of Sciences suggested that this explosion is located at $41.2982^{\circ}$ N, 129.0742 ${ }^{\circ} \mathrm{E}$ and the seismic magnitude was Mb 5.56 (Wen, 2017; Zhao et al., 2017). This site refers to the Punggye-ri nuclear weapon test site, where the previous five nuclear weapons tests were conducted by North Korea. The estimated yield of this test is about 108 kt TNT, being the largest nuclear test among all 6 tests by North Korea, which is about 3 - 7.8 times bigger than that of "Fat Man" atomic bomb detonated over Nagasaki in 1945 (Wen, 2017).

The emergency response of environmental monitoring was immediately initiated by China (Ministry of Environmental Protection of the People’s Republic of China, 2017), South Korea and Japan (The Nuclear Regulation Authority of Japam, 2017) by monitoring the radioactivity level in the border area to North Korea using routine radioactive monitoring methods, but no measurable signals have been reported. It is expected to confirm this event by investigating the radioactive signal directly released from this test by using a highly sensitive method, which will be also useful for evaluation of the possible environmental impact.

${ }^{14} \mathrm{C}$ with a half-life of 5730 years, is produced as a neutron activation product through reactions of ${ }^{14} \mathrm{~N}(\mathrm{n}, \mathrm{p}){ }^{14} \mathrm{C},{ }^{13} \mathrm{C}(\mathrm{n}, \mathrm{g}){ }^{14} \mathrm{C},{ }^{16} \mathrm{O}(\mathrm{n}, \alpha){ }^{14} \mathrm{C}$ and $\left.{ }^{15} \mathrm{~N}(\mathrm{n}, \mathrm{d}){ }^{14} \mathrm{C}\right)$ in nuclear weapon tests and nuclear reactors, and often released to the atmosphere as gaseous form (e.g. $\left.\mathrm{CO}_{2} / \mathrm{CO}\right) .{ }^{129} \mathrm{I}$, a radioisotope of iodine with half-life of $15.7 \times 10^{6}$ years, is produced as a 
fission product of ${ }^{235} \mathrm{U}$ and ${ }^{239} \mathrm{Pu}$, and releases to the atmosphere as gaseous form (e.g. I2) from nuclear weapon tests, nuclear accidents and nuclear spent fuel reprocessing. ${ }^{14} \mathrm{C}$ and

${ }^{129}$ I level in the environment have been raised by a few orders of magnitude in 1950-1980 due to intensive atmospheric nuclear weapons tests (Hou et al., 2009; Hua et al., 2013). ${ }^{14} \mathrm{C}$ and ${ }^{129} \mathrm{I}$ are two important radionuclides released from human nuclear activities such as nuclear weapons tests, nuclear accidents, spent nuclear fuel reprocessing plants, and therefore can be applied as excellent tracers for monitoring nuclear weapons testing and nuclear accidents/leakage. Accelerator mass spectrometry (AMS) is a very sensitive method for determination of long-lived radionuclides, especially ${ }^{14} \mathrm{C}$ and ${ }^{129} \mathrm{I}$, down to $\mathrm{nBq}$ level, therefore it can be used to detect very small releases of ${ }^{14} \mathrm{C}$ and ${ }^{129} \mathrm{I}$ to the environment from nuclear activities.

Using a highly sensitive tool of AMS measurement for ${ }^{129} \mathrm{I}$ and ${ }^{14} \mathrm{C}$ in air samples, this work aims to explore the possible releases of radioactive substances from the 6th nuclear weapon test of North Korea, and estimate its impact on environmental radioactivity in the Chinese inland area.

\section{Method}

\section{Sampling}

The aerosol samples were collected by a large volume sampler (flow rateof $1.5 \mathrm{~m}^{3} / \mathrm{min}$ ) on glass fiber filter at the Xi' an AMS center (34²13'25"N, 1090'0"E) in Xi'an, China (Fig. 1). The sampling site is approximately $2200 \mathrm{~km}$ southwest of the Punggye-ri nuclear weapon test site $\left(41.2982^{\circ} \mathrm{N}, 129.0742^{\circ} \mathrm{E}\right)$ in mountain terrain, Kilju County, North 
Hamgyong Province in northeastern North Korea. The samples collected before and immediately after the North Korea sixth nuclear weapon test were analyzed for radioactive ${ }^{14} \mathrm{C}$ and ${ }^{129} \mathrm{I}$.

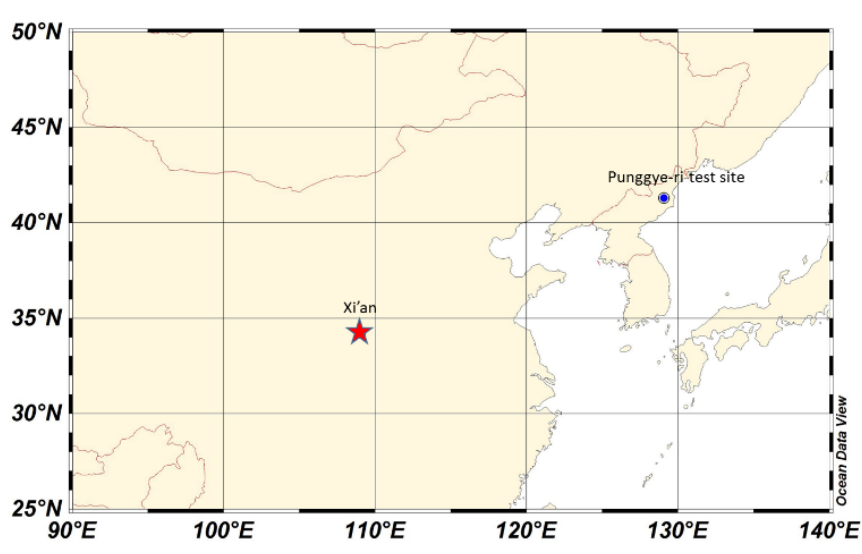

Figure 1. Map showing the Punggye-ri nuclear test site of the North Korea underground nuclear test on 3rd Sept., 2017 and aerosol sampling location in Xi’an, China

\section{Preparation of aerosol samples and AMS measurement for ${ }^{14} \mathrm{C}$}

The aerosol samples were cut into small pieces $(<2 \times 2 \mathrm{~mm})$, and put into a quartz tube for separation of carbon using pyrolysis. Carbon in aerosols was oxidized to carbon dioxide using high purity oxygen at $900{ }^{\circ} \mathrm{C}$. Carbon dioxide collected during pyrolysis process were reduced to graphite using zinc metal powder in the presence of iron as a catalyst. The ${ }^{14} \mathrm{C}$ content in the prepared graphite was measured using 3MV AMS (HVEE, the Netherlands) in the Xi' an AMS Center, The measurement uncertainty of ${ }^{14} \mathrm{C} /{ }^{12} \mathrm{C}$ atomic ratio for the samples is better than $0.2 \%$ (Cheng et al., 2013). The minimum measurable ratio of ${ }^{14} \mathrm{C} /{ }^{12} \mathrm{C}$ is $3.1 \times 10^{-16}$ (Zhou et al., 2006).

The ${ }^{14} \mathrm{C}$ level in the aerosol samples is expressed as $\Delta{ }^{14} \mathrm{C}$, which is the deviation (in \%o) of the ${ }^{14} \mathrm{C} /{ }^{12} \mathrm{C}$ ratio of a sample with respect to modern carbon (standard sample) after 
correcting for the age and isotopic fractionation (Stuiver and Polach, 1977).

\section{Preparation of aerosol samples and determination of ${ }^{129} \mathrm{I}$ and ${ }^{127} \mathbf{I}$}

The aerosol samples were cut into small pieces $(<5 \times 5 \mathrm{~mm})$, and put into a quartz boat.

${ }^{125}$ I was added as chemical yield tracer. Iodine was separated from the aerosol filter using a combustion method by being oxidized to molecular iodine with oxygen at $800{ }^{\circ} \mathrm{C}$ in a tube furnace (Hou et al., 2010). The released iodine was trapped into a mixture solution of 0.5 $\mathrm{mol} / \mathrm{L} \mathrm{NaOH}$ and $0.02 \mathrm{~mol} / \mathrm{L} \mathrm{NaHSO}_{3}$. An aliquot of solution $(1.0 \mathrm{ml})$ was taken for determination of ${ }^{127}$ I using ICP-MS (Agilent 8800, USA) after 10-fold dilution with deionized water of 18.2 M $\Omega \mathrm{cm}$, produced by a Cascada ${ }^{\mathrm{TM}}$ Lab Water System (Pall Life Sciences, USA). $\mathrm{Cs}^{+}(\mathrm{CsCl})$ was used as an internal standard in the ICP-MS measurement of iodine. One $\mathrm{mL}$ of the solution was taken for measurement of ${ }^{125} \mathrm{I}$ by a NaI gamma counter (Model FJ2021, Xi'an Nuclear Instrument Factory, China). 0.2 mg ${ }^{127}$ I carrier and $0.5 \mathrm{mg}$ chloride were added to the remained solution, and then nitric acid was added to $\mathrm{pH}$ 2. $\mathrm{AgNO}_{3}$ solution was added to the solution, and the formed AgI-AgCl precipitate was separated by centrifuge. After dried at $70^{\circ} \mathrm{C}$, the $\mathrm{AgI}-\mathrm{AgCl}$ precipitate was mixed with $\mathrm{Nb}$ metal powder (99.9\%, 325 mesh, Alfa Aesar, USA) in mass ratio of 1:3 and pressed into a cooper target holder. ${ }^{129} \mathrm{I}$ in the AgI-AgCl precipitate was measured using 3MV AMS in the Xi' an AMS Center (Hou et al., 2010). The procedural blank of ${ }^{129} \mathrm{I} /{ }^{127} \mathrm{I}$ was prepared using a blank glass fiber filter with the same procedure as for the samples, and determined to be $<2 \times 10^{-13}$ (Zhou et al., 2010). ${ }^{129} \mathrm{I} /{ }^{127}$ I standard was prepared using NIST-SRM 4949c by dilution using ${ }^{127} \mathrm{I}$ carrier solution (prepared using iodine crystal with ${ }^{129} \mathrm{I} /{ }^{127} \mathrm{I}$ atomic ratio 
of less than $2 \times 10^{-14}$ ) in the same form as sample (AgI-AgCl precipitate), which is used for calibration/correction of the measured ${ }^{129} \mathrm{I} /{ }^{127} \mathrm{I}$ ratio by AMS.

\section{Results and discussion}

\section{Levels of $\Delta{ }^{14} \mathrm{C}$ and ${ }^{129} \mathrm{I}$ in the aerosols}

The pre- and post-test aerosol samples were analyzed for both ${ }^{14} \mathrm{C}$ and ${ }^{129} \mathrm{I} . \Delta{ }^{14} \mathrm{C}$ levels range from $-450 \%$ o to $-530 \%$ o for pre-test aerosols, while from $-485 \%$ o to $-627 \%$ o for posttest samples (Fig.2a). No significant difference of $\Delta^{14} \mathrm{C}(\mathrm{p}=0.22)$ between pre-test and posttest was measured. However, $\Delta{ }^{14} \mathrm{C}$ values in these aerosol samples are significantly lower than those observed in atmospheric $\mathrm{CO}_{2}$ samples collected all over China with $\Delta^{14} \mathrm{C}$ ranging from -20\%o to -30\%o (Niu et al., 2016).

Concentrations of stable iodine $\left({ }^{127} \mathrm{I}\right)$ in aerosol were measured to be $1.2-6.0 \mathrm{ng} / \mathrm{m}^{3}$ (Table 1), which fell well in the common level of iodine in terrestrial aerosols (Saiz-Lopez et al., 2012). ${ }^{129} \mathrm{I}$ concentrations range from $0.3 \times 10^{5}$ atoms $/ \mathrm{m}^{3}$ to $4.6 \times 10^{5}$ atoms $/ \mathrm{m}^{3}$ (Table $1)$.

\section{Table 1 Analytical results of ${ }^{127} I,{ }^{129} I$ concentrations and ${ }^{129} I /{ }^{127} I$ atomic ratios in} Xi’an aerosols

\begin{tabular}{|c|c|c|c|c|c|c|c|}
\hline \multirow{2}{*}{$\begin{array}{l}\text { Sample } \\
\text { Name }\end{array}$} & \multirow{2}{*}{$\begin{array}{c}\text { Sampling } \\
\text { date, } \\
2017\end{array}$} & \multicolumn{2}{|c|}{${ }^{127} \mathrm{I}, \mathrm{ng} / \mathrm{m}^{3}$} & \multicolumn{2}{|c|}{${ }^{129} \mathrm{I}, \times 10^{5}$ atoms $/ \mathrm{m}^{3}$} & \multicolumn{2}{|c|}{${ }^{129} \mathrm{I} /{ }^{127} \mathrm{I}$ atomic ratio, $\times 10^{-8}$} \\
\hline & & Conc. & Uncertainty & Conc. & Uncertainty & Ratio & Uncertainty \\
\hline AE002 & $3.28-3.30$ & 5.8 & 0.2 & 4.5 & 0.2 & 1.62 & 0.07 \\
\hline AE003 & $3.30-4.01$ & 2.8 & 0.1 & 1.8 & 0.1 & 1.34 & 0.04 \\
\hline
\end{tabular}




$\begin{array}{llllllll}\text { AE004 } & 4.01-4.03 & 6.0 & 0.1 & 1.1 & 0.1 & 0.38 & 0.03 \\ \text { AE005 } & 8.28-8.29 & 1.2 & 0.1 & 0.8 & 0.1 & 1.38 & 0.06 \\ \text { AE006 } & 8.30-8.31 & 2.50 & 0.1 & 0.3 & 0.1 & 0.26 & 0.01 \\ \text { AE007 } & 9.01-9.02 & 3.5 & 0.1 & 1.2 & 0.1 & 0.75 & 0.05 \\ \text { AE008 } & 9.03-9.04 & 3.3 & 0.1 & 2.5 & 0.1 & 1.57 & 0.05 \\ \text { AE009 } & 9.05-9.06 & 2.1 & 0.1 & 7.3 & 0.3 & 7.43 & 0.39 \\ \text { AE010 } & 9.08-9.09 & 4.9 & 0.1 & 1.3 & 0.1 & 0.57 & 0.03 \\ \text { AE011 } & 9.10-9.11 & 1.7 & 0.1 & 4.6 & 0.1 & 5.75 & 0.24\end{array}$

* Uncertainties presented here is an extended uncertainty with a coverage of $\mathrm{k}=1$ August before the North Korean 6th nuclear weapon test, and (0.6-7.4) $\times 10^{-8}$ in early

139 September after the test (Fig. 2b). This range is comparable to those in aerosols collected in Japan and Brazil, while 1-2 orders of magnitude lower than those in European (Englund et al., 2010; Santos et al., 2005; Toyama et al., 2013).

142 It is worthy to note that the average ${ }^{129} \mathrm{I} /{ }^{127} \mathrm{I}$ atomic ratio of post-test aerosol samples 143 is 4.7 times higher than that of pre-test samples (Fig. 2b). High ${ }^{129} \mathrm{I} /{ }^{127} \mathrm{I}$ ratios were observed 144 in two aerosol samples collected on 5-6 Sept. and 10-11 Sept. However, statistical analysis 145 suggests that there is no significant difference between pre-test ${ }^{129} \mathrm{I} /{ }^{127} \mathrm{I}$ ratios and those post-test ones $(\mathrm{p}=0.16)$ because of high variation of ${ }^{129} \mathrm{I} /{ }^{127} \mathrm{I}$ ratios in these samples. 


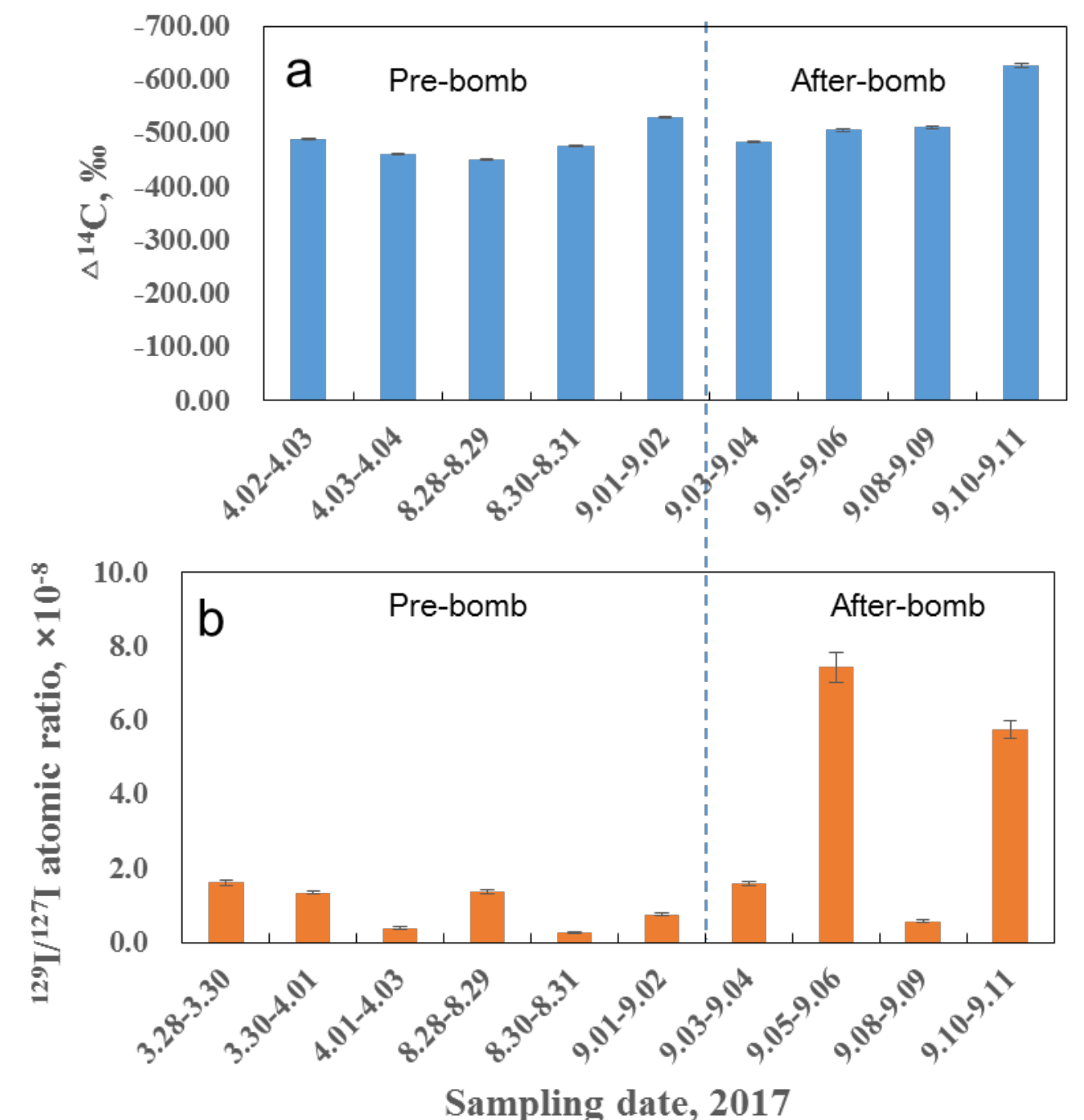

Figure 2. Comparison of $\Delta^{14} \mathrm{C}$ and ${ }^{129} \mathrm{I} /{ }^{127} \mathrm{I}$ levels in aerosols from Xi'an, China before and

$$
\text { after the North Korea } 6^{\text {th }} \text { nuclear weapon test }
$$

\section{Sources of ${ }^{14} \mathrm{C}$ and ${ }^{129} \mathrm{I}$ in aerosols from Xi'an}

No significantly statistical difference of ${ }^{14} \mathrm{C}$ concentrations in aerosols was noticed between before and after North Korea 6th nuclear weapon test. In fact, the significantly low $\Delta^{14} \mathrm{C}$ values (from -450\% to -627\%) measured in these aerosol samples indicate that these aerosols contained high ${ }^{14} \mathrm{C}$-depleted “old carbon” mainly from combustion of fossil fuel (Paull et al., 1989), which greatly reduce the atmospheric $\Delta{ }^{14} \mathrm{C}$ (Niu et al., 2016). Therefore, the $\Delta^{14} \mathrm{C}$ results suggest the ${ }^{14} \mathrm{C}$ signal of North Korea nuclear test, if it exists, would be 
negligible or completely masked by “old carbon” signals.

The increased ${ }^{129} \mathrm{I} /{ }^{127} \mathrm{I}$ ratios in the aerosol samples collected immediately after the nuclear weapon test was observed (Fig. 2), which is probably originated from the North Korean $6^{\text {th }}$ nuclear weapons test. However, this is not in agreement with the results of radiation monitor along the board areas between China and North Korea, where no increased absorption dose rate was measured in air (Ministry of Environmental Protection of the People’s Republic of China, 2017; Persio, 2017).

To confirm the source of ${ }^{129} \mathrm{I}$ in the aerosol samples immediately after North Korean nuclear weapon test on 3rd Sept. 2017, the pathway of the air masses in Xi'an in the periods for collection of these samples was investigated using transport and dispersion modelling (HYSPLIT) (Draxler and Rolph, 2003) (Fig. 3). Back trajectories analysis shows that the air masses at the sampling site in Xi'an, China during the sampling periods are dominantly transported from direction of west and northwest, and in a small portion from east and southeast but within the territory of China. Therefore, the high ${ }^{129} \mathrm{I} /{ }^{127} \mathrm{I}$ ratios and ${ }^{129} \mathrm{I}$ concentrations in these aerosol samples should be related to the air masses from west Asia and Europe during 26th - 30th Mar., 31st Aug. - $4^{\text {th }}$ Sept., and 10th-11th Sept. Due to the huge amount of ${ }^{129} \mathrm{I}$ has being released from the nuclear fuel reprocessing plants at Sellafield, UK and La Hague, France, level of aerosol ${ }^{129} \mathrm{I} /{ }^{127} \mathrm{I}$ ratios in Europe has been increased to (15.6-102.0) $\times 10^{-8}$ (Zhang et al., 2016), which is 1-2 orders of magnitude higher than those in Xi'an. Consequently, the increased ${ }^{129} \mathrm{I}$ level should be attributed to ${ }^{129}$ I-rich air masses which carry gaseous released ${ }^{129} \mathrm{I}$ and re-emission of liquid discharged ${ }^{129}$ I from the European nuclear fuel reprocessing plants (Sellafield, UK and La Hague, France) (Zhang et al., 2017), and unlikely related to the North Korea nuclear weapon test on 3rd Sept. 2017. 

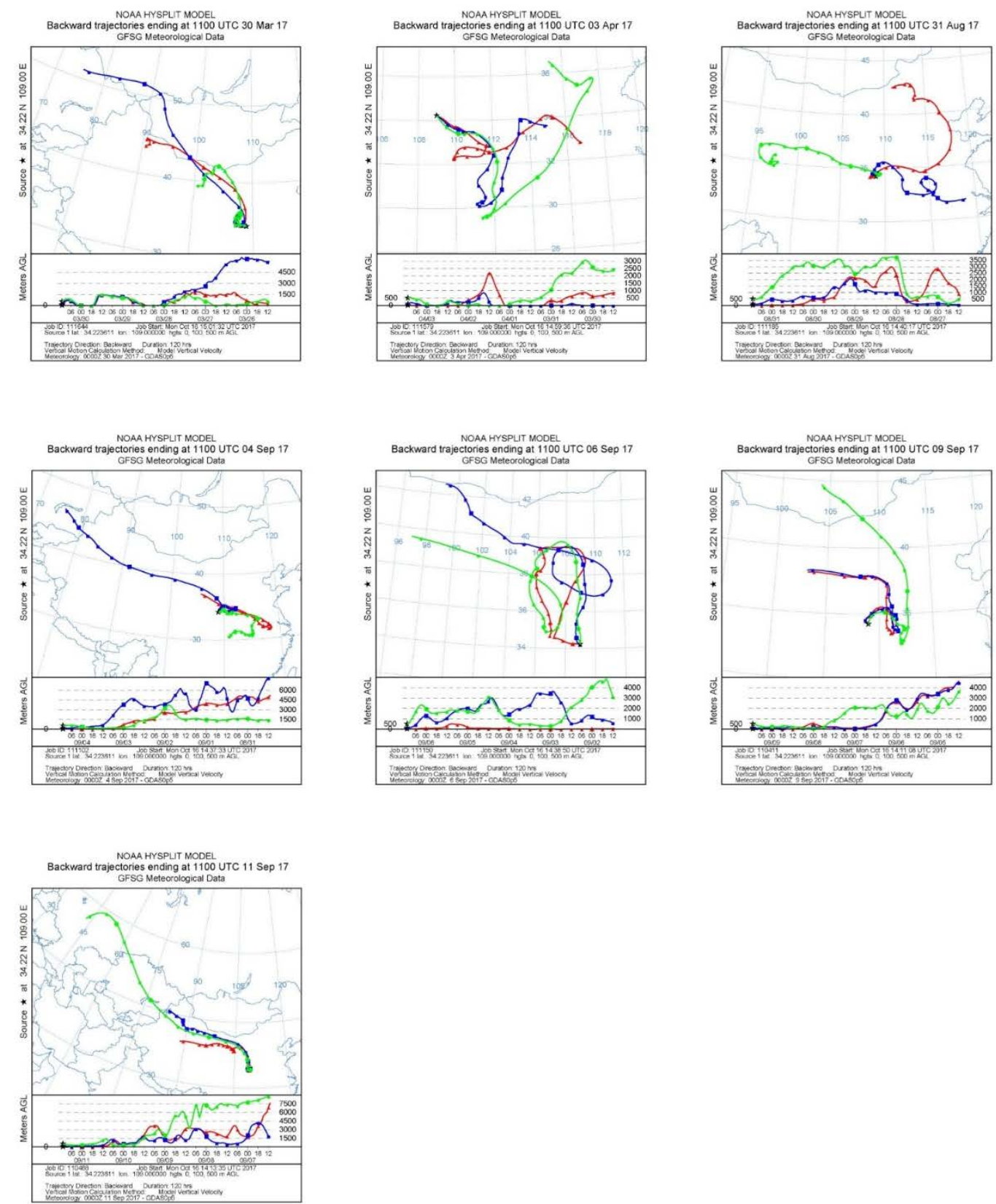

Figure 3. Back trajectories analysis of air masses in Xi’an from 30th Mar. to 11th Sept. 2017.

\section{Radiation impact of North Korea 6th nuclear test on Chinese inland} in inland China, which agrees with the monitoring results along the boards areas between 
191

192

193

194

195

196

197

198

199

200

201

202

203

204

China and North Korea (Ministry of Environmental Protection of the People’s Republic of China, 2017; The Nuclear Regulation Authority of Japam, 2017).

The forward trajectory analysis shows that the air masses moved from the Punggye-ri nuclear test site on 3rd Sept. to north and northeast direction (Fig. 4). It indicates that even if there is any leakage of radioactive substances from this nuclear test, the radioactive pollutants should be transported northwards along Chinese northeast border (Jilin and Heilongjiang provinces) to southeast Russia, and impossible to reach Xi'an, China. It is also evident that the latest nuclear test would not cause an impact in the environment and human health in China.

Up to now, no radioactive substances have been detected in neighboring countries of North Korea (i.e. Japan, South Korea). However, owing to the collapse of nuclear test tunnel in late September, new radiation leakage through the mountain cracks is quite possible, which have attracted much attention. We continue to collect air samples and would further investigate its impact on Chinese environment. 


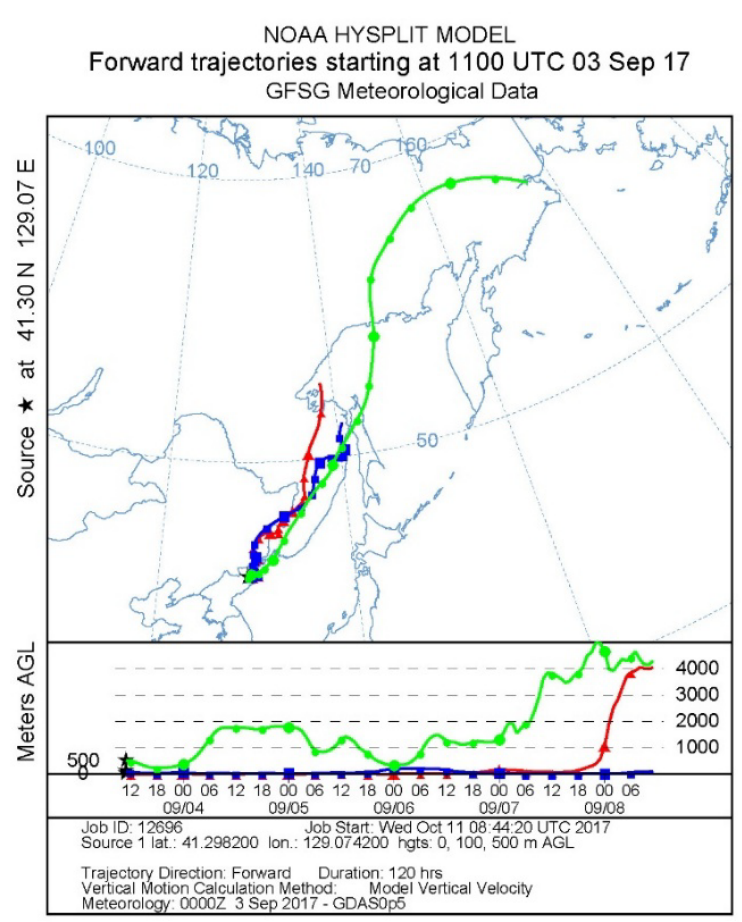

\section{Conclusions}

Based on the results obtained in this work and discussion above, it can be concluded that: (1) ${ }^{14} \mathrm{C}$ levels in the aerosols in Xi'an, China do not show any signals from the North Korean 6th nuclear weapon test. On the contrary, a much lower ${ }^{14} \mathrm{C}$ level was observed in 212 the sampling period compared to ${ }^{14} \mathrm{C}$ level of atmospheric $\mathrm{CO}_{2}$ all over China, which should be attributed to dilution effect of ${ }^{14} \mathrm{C}$-depleted “old carbon” from combustion of fossil fuel; (2) A 4.7-fold increase of ${ }^{129} \mathrm{I} /{ }^{127} \mathrm{I}$ ratios were measured in the post-test samples compared to the pre-test ones. The back and forward trajectory analysis show that the increased ${ }^{129} \mathrm{I} /{ }^{127} \mathrm{I}$ ratios in the aerosols collected immediately after the North Korean nuclear weapon test are attributed to the ${ }^{129}$ I-enriched air masses contaminated by emission of radioiodine 
from the European nuclear reprocessing plants. The results of this work suggest no measurable leakage of radioactive substances released from the North Korea $6^{\text {th }}$ underground nuclear test, therefore no radiation impact to the environment and human health.

\section{Acknowledgements}

This work was supported by the National Natural Science Foundation of China (No. 11605207 and 91643206), the Ministry of Science and Technology of China (No. 2015FY110800), and the Technology Foundation for Selected Overseas Chinese Scholar, Department of Human Resources And Social Security of Shaanxi Province, China.

\section{References}

Cheng, P., Zhou, W., Wang, H., Lu, X., Du, H., 2013. ${ }^{14} \mathrm{C}$ dating of soil organic carbon (SOC) in loess-paleosol using sequential pyrolysis and accelerator mass spectrometry (AMS). Radiocarbon 55, 563-570. doi:10.2458/azu_js_rc.55.16185

Draxler, R.R., Rolph, G.D., 2003. HYSPLIT (HYbrid SingleParticle Lagrangian Integrated Trajectory) Model, access via NOAA ARL READY Website, http://www.arl.noaa.gov/ready/ hysplit4.html. NOAA Air Resour. Lab.

Englund, E., Aldahan, A., Hou, X., Possnert, G., Soderstrom, C., 2010. Iodine (I-129 and I-127) in aerosols from northern Europe. Nucl. Instrum. Meth. B 268, 1139-1141.

Hou, X., Hansen, V., Aldahan, A., Possnert, G., Lind, O.C., Lujanienè, G., 2009. A 
review on speciation of iodine-129 in the environmental and biological samples. Anal. Chim. Acta 632, 181-196.

Hou, X., Zhou, W.J., Chen, N., Zhang, L., Liu, Q., Luo, M., Fan, Y., Liang, W., Fu, Y., 2010. Determination of Ultralow Level ${ }^{129} \mathrm{I} /{ }^{127} \mathrm{I}$ in Natural Samples by Separation of Microgram Carrier Free Iodine and Accelerator Mass Spectrometry Detection. Anal. Chem. 82, 7713-7721. doi:10.1021/ac101558k

Hua, Q., Barbetti, M., Rakowski, A.Z., 2013. Atmospheric Radiocarbon For The Period 1950-2010. Radiocarbon 55, 1-14.

Ministry of Environmental Protection of the People’s Republic of China, 2017. Environmental radiation monitoring results of the sixth North Korean nuclear test in the northeast border and surrounding areas.

Niu, Z., Zhou, W., Wu, S., Cheng, P., Lu, X., Xiong, X., Du, H., Fu, Y., Wang, G., 2016. Atmospheric Fossil Fuel $\mathrm{CO}_{2}$ Traced by $\Delta^{14} \mathrm{C}$ in Beijing and Xiamen, China: Temporal Variations, Inland/Coastal Differences and Influencing Factors. Environ. Sci. Technol. 50, 5474-5480. doi:10.1021/acs.est.5b02591

Paull, C.K., Martens, C.S., Chanton, J.P., Neumann, A.C., Coston, J., Jull, A.J.T., Toolin, L.J., 1989. Old carbon in living organisms and young $\mathrm{CaCO}_{3}$ cements from abyssal brine seeps. Nature 342, 166-168. doi:10.1038/342166a0

Persio, S.L., 2017. North Korean Soldiers Are Being Treated for Radiation Exposure After Nuclear Test: Report. Newsweek. http://www.newsweek.com/north-koreansoldiers-being-treated-radiation-exposure-after-nuclear-test-698246 
Glasow, R., Carpenter, L.J., McFiggans, G., 2012. Atmospheric chemistry of iodine. Chem. Rev. 112, 1773-1804.

Santos, F.J., López-Gutiérrez, J.M., García-León, M., Suter, M., Synal, H.A., 2005. Determination of ${ }^{129} \mathrm{I} /{ }^{127} \mathrm{I}$ in aerosol samples in Seville (Spain). J. Environ. Radioact. 84, 103-109.

Stuiver, M., Polach, H.A., 1977. Discussion: reporting of ${ }^{14} \mathrm{C}$ data. Radiocarbon 19, 355363.

The Nuclear Regulation Authority of Japam, 2017. Estimated and measured 1m height environmental radioactivity level at monitoring posts in 47 prefectures all over Japan. http://www.nsr.go.jp/english/.

Toyama, C., Muramatsu, Y., Igarashi, Y., Aoyama, M., Matsuzaki, H., 2013. Atmospheric fallout of ${ }^{129} \mathrm{I}$ in Japan before the Fukushima accident: Regional and global contributions (1963-2005). Environ. Sci. Technol. 47, 8383-8390. doi:10.1021/es401596z

Wen, L., 2017. University of Science and Technology of China accurately determines the location and yield of North Korea underground nuclear detonation on September 3, 2017. http://seis.ustc.edu.cn/2017/0903/c10094a191087/page.htm?from=timeline\&isappins talled $=0$.

Zhang, L., Hou, X., Li, H., Xu, X., 2017. A 60-year record of ${ }^{129}$ I in Taal Lake sediments (Philippines): Influence of human nuclear activities at low latitude region. Chemosphere. doi:10.1016/j.chemosphere.2017.11.134 
Zhang, L., Hou, X., Xu, S., 2016. Speciation of ${ }^{127} \mathrm{I}$ and ${ }^{129} \mathrm{I}$ in atmospheric aerosols at Risø, Denmark: Insight into sources of iodine isotopes and their species transformations. Atmos.Chem.Phys. 16, 1971-1985.

Zhao, L., Xie, X., He, X., Zhao, X., Yao, Z., 2017. Preliminary investigations on the seismic identification, depth and yield estimate of North Korea underground nuclear test on September 3, 2017. http://www.igg.cas.cn/xwzx/kyjz/201709/t20170904_4854427.html.

Zhou, W., Zhao, X., Lu, X., Liu, L., Wu, Z., Cheng, P., Zhao, W., Huang, C., 2006. The 3MV multi-element AMS in Xi'an, China: unique features and preliminary tests. Radiocarbon 48, 285-293.

Zhou, W.J., Hou, X., Chen, N., Zhang, L.Y., Liu, Q., He, C.H., Luo, M.Y., Liang, W.G., Fan, Y.K., Wang, Z.W., Fu, Y.C., Li, H.B., 2010. Preliminary study of radioisotope ${ }^{129}$ I application in China using Xi'an accelerator mass spectrometer. ICNS News 25, 8-23. 